\title{
TTR
}

Traduction, terminologie, re?daction

\section{Translating Culture: Reading the Paratexts to Aimé Césaire's Cahier d'un retour au pays natal}

\section{Richard Watts}

Volume 13, numéro 2, 2e semestre 2000

Les Antilles en traduction

The Caribbean in Translation

URI : https://id.erudit.org/iderudit/037410ar

DOI : https://doi.org/10.7202/037410ar

Aller au sommaire du numéro

Éditeur(s)

Association canadienne de traductologie

ISSN

0835-8443 (imprimé)

1708-2188 (numérique)

Découvrir la revue

Citer cet article

Watts, R. (2000). Translating Culture: Reading the Paratexts to Aimé Césaire's Cahier d'un retour au pays natal. TTR, 13(2), 29-45.

https://doi.org/10.7202/037410ar
Résumé de l'article

Traduire la culture : La lecture des paratextes au Cahier d'un retour au pays natal d'Aimé Césaire - Cet article traite non pas de la traduction linguistique d'un texte antillais, mais de sa traduction culturelle. Il présente l'argument que les paratextes aux nombreuses éditions du Cahier d'un retour au pays natal d'Aimé Césaire fonctionnent principalement en tant qu'instruments de traduction culturelle. Il décrit aussi comment les transfigurations du paratexte au Cahier à travers le temps et les cultures servent à marquer les épistémès changeants de la « culture antillaise » et de la « littérature francophone antillaise ».
Tous droits réservés (C) TTR: traduction, terminologie, rédaction — Les auteurs, 2000
Ce document est protége par la loi sur le droit d'auteur. L'utilisation des services d'Érudit (y compris la reproduction) est assujettie à sa politique d'utilisation que vous pouvez consulter en ligne.

https://apropos.erudit.org/fr/usagers/politique-dutilisation/ 


\section{Translating Culture: Reading the Paratexts to Aimé Césaire's}

\section{Cahier d'un retour au pays natal'}

\section{Richard Watts}

From the moment of its first publication in book form in 1942 to its most recent edition, Aimé Césaire's Cahier d'un retour au pays natal has come wrapped in a great variety of paratextual skins. Whereas the 1942 edition is a slim, unassuming volume with a few illustrations and a brief preface, the paratextual apparatuses from two critical editions of the 1990s dwarf the text itself. The comparison of the mere volume of the Cahier at these two moments of publication begins to indicate just how the status of Césaire's text has changed over the last 50 years. However, the increasing popularity or even canonisation of the Cahier is not my concern here. Examining the Cahier's paratext at not just these two moments of publication but also at the many moments in between will allow me to confront a different problematic: How, over the years, have the different paratexts to the Cahier conditioned the reception of this now-canonical text? I will argue here that they have served - and continue, to some degree, to serve - as instruments of cultural translation. As Césaire's text radiated out to new publishing

\footnotetext{
${ }^{1}$ A first version of this article was delivered on November 5, 1998 at the International Conference on Caribbean Literatures in Nassau, the Bahamas. I would like to thank those present whose comments helped shape the final version; in particular, Bernadette Cailler, Elisabeth Mudimbe-Boyi, and Richard Serrano. Unless otherwise noted in the bibliography, all translations are mine.
} 
contexts (from Cuba to the U.S. to France and out into the boundless space of "world literature"), the prefaces, afterwords, titles, covers, illustrations, glossaries etc. that constitute the paratext all worked to a greater or lesser extent to render the culturally unfamiliar less so. But before interrogating the paratexts to a number of editions of Césaire's Cahier, it will first be useful to consider the paratext from a broader perspective.

What are paratexts generally thought to do? Until recently, the definitive word on the subject came from Gérard Genette's Seuils (1987). It was some years ago now that Genette first dissected the paratext, the apparatus that surrounds and, in some cases, mingles with the text. A virtual Gray's Anatomy of the liminal spaces of the book, Seuils, or Paratexts (1997), as the work is known in English, dismantles the book or "text-object" in order to lay bare all of the elements that frame the text proper. Genette labels and classifies these paratextual elements and describes the effects they are intended to have on the reader's encounter with the "text". Although Genette considers examples from a large array of contexts and periods (he examines the paratexts to Homer's epics as well as those to Thomas Pynchon's antinarratives, with much in between), his study remains resolutely and unselfconsciously synchronic. As Genette puts it, "it is appropriate to define objects before one studies their evolution" (Genette, 1997, p. 13). To fulfil his mandate, Genette dissects the text-object in the manner of a forensic pathologist by peeling back, one by one, the layers that envelope the unmediated text and that separate it from the reader. Genette starts his dissection as far away from the text as what he calls the epitext (public interviews granted by the author in which he or she refers to the work) and moves as close to the text as chapter headings and epigraphs, maintaining all the while the laboratory conditions - in this case, a static, synchronic gaze - required of this kind of typological analysis.

As suggested above, Genette's synchronic analysis is principally concerned with the rhetoric of the paratext. In discussing,

\footnotetext{
${ }^{2}$ The quotation marks are meant to indicate my discomfort with text/paratext distinction. Making that distinction suggests that the text could potentially be experienced in an unmediated fashion. This is only possible within a structuralist's laboratory. This article seeks to move toward a richer understanding of the interaction between text and paratext, one that necessarily blurs the distinction between the two.
} 
for instance, the allographic preface (a preface written by someone other than the author), Genette identifies "recommendation" as its most important function: "(T)he function of recommending usually remains implicit because the mere presence of this type of preface is in itself a recommendation" (Genette, 1997, p. 268). An allographic preface by Sartre, to cite one of Genette's preferred préfaciers, signals to the reader the quality, seriousness, and perhaps even political orientation of the text in question. But when Genette describes the effect that an allographic preface is meant to have, the reader that Genette imagines or has to imagine, given the synchronic perspective he has purposefully adopted - is a sort of cultural universal, a reader out of time and place. As this implies, Genette is not concerned with what the paratext tells us about readers and the changing contexts in which they read. Likewise, Genette assumes that the reader and the text share a common cultural code. This is not the case with most of what is referred to as Francophone literature, at least as far as its disproportionally metropolitan readership is concerned.

Still, although Genette privileges the synchronic, he recognises in the introduction to Paratexts the value in extending the analysis of these textual thresholds into the diachronic - in other words, of considering the transfigurations over time of the paratext to a particular text - since the paratext is, as he admits, "the most socialised side of the practice of literature (the way its relations with the public are organised)" (Genette, 1997, p. 14). To put a finer point on this line of inquiry that Genette identifies but does not pursue, each edition of a work and, by extension, each paratext addresses a culturally-specific moment and a culturally-specific readership, thereby projecting a singular version of the text through the lens of the chronotope (time/place) of its publication. This implies, of course, that the text which cannot be divorced from its frame - is subject to shifting interpretations as a result, to a greater or lesser degree, of the paratext that surrounds it.

It is from this perspective, then, that it is possible to refer to the paratext as an instrument of cultural translation. As Genette avers, the primary function of paratexts in all contexts is to attract readers, to draw them toward and into the book. But with works by a perceived cultural Other, the secondary function of the paratext (which Genette presents as being one of explanation and guidance) is one of cultural translation, especially for the metropolitan readership, the editions I will be considering generally targeted. The paratexts to works of 
Francophone literature, especially those works written prior to the post/colonial period ${ }^{3}$, tend to present the text as culturally foreign, exotic, or different, but also as ultimately interpretable. Many of the prefaces - to cite perhaps the most important element of the paratext to early works of Francophone colonised literature from the 1920s and 1930 s contain a distinctly anthropological discourse in which a preface writer, most often from metropolitan France, recounts his travels in the colony and his contact with the "native" writer and his culture. By the time the Cahier is first published, a lot has changed. But even with texts by Césaire's contemporaries in the colonial universe, the paratext to the work of a perceived Other typically functions as an apparatus of cultural translation by evoking the work's (or its author's) difference while rendering that difference familiar or knowable.

The Cahier d'un retour au pays natal and its paratexts are a particularly rich source for this type of analysis because of the text's many editions published in a number of countries and languages, and the apparent problems of cultural translatability (not to mention linguistic translatability) that the text poses. It is also a compelling object for this type of study since this itinerant text provides, in each of its publishing chronotopes, a view of the evolving ideas or epistemes of the Caribbean and of "Francophone Caribbean Literature" and the place of Césaire's poem within or outside of those categories. It is with a view to capturing these epistemological shifts that I will consider the different paratexts to the Cahier in chronological order.

$* * *$

The paratext to the first book version of the Cahier constitutes, perhaps surprisingly, one of its most successful cultural translations. It can be assumed from the elements that make up the paratext - illustrations by a Cuban painter and a preface by a French Surrealist with a background in Latin American aesthetics - that this is largely a function of the chronotope of its publication. In 1942, three years after the quiet first

\footnotetext{
${ }^{3}$ I borrow this particular version of the term from Chris Bongie who insists on the "epistemic complicity" (Bongie, 1998, p. 13) between the colonial and the postcolonial by inserting a slash after the prefix ("post/colonial"). This idea of the epistemic complicity or continuity between these two periods is relevant to my work because many so-called Francophone texts will continue to be framed in a colonial (which is to say traditional ethnographic) manner well into the postcolonial period.
} 
appearance of the Cahier in the Paris-based Surrealist journal Volontés ${ }^{4}$, the Cuban publisher Molina y Compania published Retorno al pais natal, a translation into Spanish of the Cahier by Lydia Cabrera. This edition, destined for a local Hispanophone audience, situates the Cahier in the Caribbean while acknowledging in subtle ways the wealth of cultural influences that inform it.

The most striking paratextual elements here are the sketches by the Cuban painter Wilfredo Lam that appear on the cover and throughout the book. The link between Lam and Césaire is not a gratuitous one. Not only were the two friends, they were also working on similar aesthetic and political projects in their respective domains. The appreciations of Lam (and, it should be noted, of Lydia Cabrera) in Césaire's wartime journal Tropiques ( ${ }^{\text {os }}$ 6-7, Feb. 1943, pp. 61-62) only serve to confirm this allegiance. This connection is significant because the visual paratext, designed principally to catch the prospective reader's eye, proves often in the case of "colonized" literature to be a poor translation of the work to which it is attached. Lam's work, however, is a particularly potent vehicle for translating Césaire's poetry. Both make use, in their respective media, of the vocabulary and syntax of the European avant-garde of the 1920s and 1930 s at the same time that they inflect this vocabulary to make it reflect Caribbean realities and to present what they consider a nascent Afro-Caribbean consciousness. The figures in Lam's drawings seem to draw strength from a communion with the natural forces of the Caribbean, imagery similar to the type that appears at various points in Césaire's epic poem. Both also infuse their works with references to the African cultural heritage that they were re-discovering at the time. For the Cuban and, more broadly, Latin American audience that this paratext addresses, Lam's drawings situate the Cahier precisely in the Caribbean, and create resonance with the afro-cubanismo and negrismo movements taking hold of the island in those years.

Other elements of the paratext point to the emergence of a diasporic consciousness in the Caribbean. Even the name of the translator, Lydia Cabrera, on the cover of the book reinforces this particular situating of the text. Cabrera, the Cuban author and

\footnotetext{
${ }^{4}$ Of this publishing event (or non-event, as was the case), Abiola Irele writes, "Césaire left Paris for Martinique shortly after the publication of the poem, which went unnoticed in the tense situation that prevailed in Paris on the eve of the Second World War..." (Irele in Césaire, 2000, p. xxviii).
} 
ethnographer, had already done significant work on the place of Yoruba language and culture in Cuba. Conducted at a time when most Cuban intellectuals still refused to acknowledge Cuba's African heritage, Cabrera's pioneering research, like Lam's radically original drawings, helped to point the Caribbean's cultural compass at least partially away from Europe and toward Africa, all the while insisting on the Caribbean particularity of the mixture of these influences. At the time of publication, such a cultural congruence between several elements of the paratext and the text itself is indeed remarkable.

But as the cover also indicates, this is in some sense a culturally-divided paratext, with, on the one hand, Lam's drawings translating the Cahier's Afro-Caribbeanness, and, on the other, a preface by the French Surrealist poet Benjamin Peret pulling the text in a different direction. For the cosmopolitan audience targeted by this edition, the name "Peret" undoubtedly signified French Surrealism. However, it also signified in the early 1940s a properly recontextualized Surrealism. Peret, André Breton, Claude Lévi-Strauss, and, incidentally, Wilfredo Lam, had all fled France in 1941 on the same ship, the Capitaine-Paul-Lemerle, and had all passed through Martinique on their way to their respective homelands or lands of exile: Breton and Lévi-Strauss to New York, Lam to Cuba, and Peret to Mexico ${ }^{5}$. Peret, along with the other Parisian intellectuals in exile, became known as an admirer of Caribbean and Latin American culture. While in Mexico, Peret began compiling some of the myths, legends, and popular narratives of the Americas that he would eventually publish in French upon his return to France some eight years later ${ }^{6}$. As a result of this literary anthropology, as well as earlier work by Peret on Brazil, the name "Peret" could also signify links to a pan-Caribbean or Latin American aesthetic practice.

The one-page preface itself is a restrained piece by the standards of the period. These are, after all, the years of the totalising preface embodied by Jean-Paul Sartre's 50-page preface ("Orphée noir") to Léopold Sédar Senghor's Anthologie de la poésie nègre et

\footnotetext{
${ }^{5}$ The most complete narration of the passage to the Antilles and the quarantine of the ship's passengers in Vichy-occupied Martinique appears in Claude LéviStrauss's Tristes tropiques (Lévi-Strauss, 1955, pp. 16-34).

${ }^{6}$ See Anthologie des mythes, légendes et contes populaires d'Amérique, éd. Benjamin Peret.
} 
malgache (totalising, in a first sense, in that Senghor's anthology became known more for Sartre's preface than for any of the poems that it contained). Peret acknowledges the universal themes of liberation and revolt contained in the work as well as its Caribbean specificity. Of the Caribbeanness of the poem, Peret writes, "Césaire, more than being the interpreter of Martinique's tropical nature, is a part of it" (Peret in Césaire, 1942, p. 3). This, it should be noted, belongs to what is now considered the exoticising Surrealist discourse that held that black writers had a more authentic connection to nature than their alienated counterparts in Europe. At the time, though, it constituted a significant granting of cultural autonomy to a colonized writer, since in the preceding decade most works in French from the colonies were presented by prefaces that described the texts as evidence of the success of the mission civilisatrice, not as manifestations of, for instance, Dahomean culture. Regardless, the Cahier provides more for Peret than local colour : "It is miraculous, encouraging, and comforting that in this year of 1942, (a year of misery and abjection) [...] a poet's singular scream piercing the opacity of a night of bombs and firing squads can be heard all the way [in Europe] from America" (Peret in Césaire, 1942, p. 3). The preface, then, situates the Cahier in the Caribbean, but renders it relevant to the events taking place in Europe at the time. The fact remains that the mere endorsement of the text by a French Surrealist signified that the Cahier was participating in something relatively familiar, knowable, and proven. A preface by a figure such as Peret, with his French literary-institutional bona fides, renders the difference of Césaire's text recuperable and readable by a nonCaribbean audience. Nonetheless, to the cosmopolitan Latin American audience for whom this edition was destined, Lam's sketches and Peret's preface together signify the status of cultural in-betweenness, a status that the text itself evokes and attempts, on some level, to resolve.

The Cahier is situated somewhat differently in the two subsequent editions, the 1947 bilingual edition published by Brentano in New York and the 1947 Bordas edition published in Paris. Except for one Wilfredo Lam drawing opposite the title page of the 1947 Bordas edition (a drawing resembling Dogon and Bambara totems that depicts a black man reaching for the sky; this drawing would become closely associated with the Cahier as it would appear in subsequent editions of the Cahier published by Présence Africaine), the only significant paratextual element in these two editions is André Breton's preface, "Un Grand poète noir." 
Although a much longer document, Breton's cultural translation of Césaire's text for its metropolitan reading audience bears comparison with Peret's. By the nature of their place in the literaryinstitutional context in France, both at least partially recuperate the Cahier into French Surrealism. One of Breton's first rhetorical moves in the preface is, in fact, to do so explicitly. In describing Césaire's wartime journal Tropiques ${ }^{7}$ and the references to Surrealists and their avatars (most notably Lautréamont) it contained, Breton writes: "Je ne me défends pas d'en avoir conçu d'emblée quelqu'orgueil : ce qu'il exprimait ne m'était en rien étranger, les noms de poètes et d'auteurs cités m'en eussent, à eux seuls, été de sûrs garants" (Breton in Césaire, 1947 [1983], p. 78) ${ }^{8}$. Later, he identifies their common project "de porter le coup de grâce au prétendu 'bon sens', dont l'impudence a été jusqu'à s'arroger le titre de 'raison' " (Breton in Césaire, 1947 [1983], p. 86). These gestures and others like them seem to draw the Cahier into the Surrealist domain in a form of cultural translation that risks eliding certain aspects of the text - namely, those that do not conform to the dictates of Surrealism as Breton defined them.?

But the preface also attempts to translate Césaire's poem on its own terms. Like Peret, Breton is recontextualized by the events of the

${ }^{7}$ It is worth noting here that the driving intellectual force behind Tropiques, Suzanne Césaire, is reduced in Breton's preface to the role of ornament: "Suzanne Césaire, belle comme la flamme du punch" (Breton in Césaire, 1947 [1983], p. 80). The elision of Suzanne Césaire in the histories of Tropiques focussed on Aimé Césaire has been noted and corrected in Abiola Irele's introduction to the Cahier (Irele in Césaire, 2000, p. xxxv).

${ }^{8}$ Although the preface is from 1947 , I am citing the page numbers from the 1983 edition in which Breton's preface becomes, significantly, part of the appendices at the back of the book. The editors at Présence Africaine suggest through this displacement that, in 1983, the Cahier no longer requires Breton's text for introduction or promotion. "Un grand poète noir" is relegated to the status of supporting document, something that helps establish the original publishing context but that is not part of the 1983 paratext's rhetoric of promotion.

9 For instance, as Sartre points out somewhat caustically in "Orphée noir", Césaire's poem lacks the gratuitous pairings of incompatible words and images favoured by the Surrealists: "( $L$ )'image surréaliste, l'éternel procédé qui consiste à jeter un pont entre les deux termes les plus éloignés en espérant sans trop y croire que ce 'coup de dés' délivrera un aspect caché de l'être" (Sartre in Anthologie, 1948, p. xxvi). 
war. Even prior to the war, Breton had spent much time in Mexico and therefore brought to the preface an understanding of the culture of the Caribbean basin. More importantly, though, his voyage of exile to New York in 1941 took him through Martinique. It is there that he met Césaire and first read the Cahier, an encounter he makes much of in his preface. Unlike Peret, though, Breton does not focus in his preface on the poem's Caribbeanness. For Breton, the Cahier's singularity is more the result of the poet's race than of his cultural/geographical situation: "(D)éfiant à lui seul une époque où l'on croit assister à l'abdication de l'esprit, [...] le premier souffle nouveau, revivifiant, apte à redonner toute confiance est l'apport d'un Noir. Et c'est un Noir qui manie la langue française comme il n'est pas aujourd'hui un Blanc pour la manier" (Breton in Césaire, 1947 [1983], p. 80) ${ }^{10}$. This translation of Césaire's specificity that focuses on the poet's race can perhaps be faulted for being excessively vague (i.e., what does it mean to be "noir"?). Still, unlike many of the prefaces to works of Caribbean literature that precede it, Breton's preface does not reduce the Cahier to an imitation of a European style or its author to an acolyte of a European literary movement. Likewise, to insist on the poet's négritude in the preface is entirely compatible with a poem that not only insists on its négritude, but also coined the term. Although Peret and Breton define Césaire's difference in slightly different terms, they both translate the text by introducing the prospective reader to the poem or poet's cultural difference in a non-reductive fashion. In this way, the paratext to the 1942 edition and the two 1947 editions constitute partially successful translations. It will be more difficult to argue for the "accuracy" of the translation in the paratexts from the decades that followed, paratexts whose translational equivalences are so dynamic as to constitute complete cultural and geographical displacements of the Cahier.

\footnotetext{
${ }^{10}$ The last assertion in that quotation elicits this reaction from Mireille Rosello: "Breton's enthusiasm is marred by his paternalistic allusion to a Black's astonishing mastery of French..." (Rosello in Césaire, 1995, p. 33). The accusation of paternalism is perhaps misdirected here. Breton seems to be suggesting that Césaire's ability to "handle" or "use" the French language which is different than Rosello's inference that "manier" means "to master" exists not in spite of his being black, but because of it. Like Sartre, Breton sees Césaire's poem as a site of the renewal of the French language, a renewal not possible in creatively impoverished wartime and postwar metropolitan France. Breton's is still a debatable assertion, but not for the reason identified by Rosello.
} 
The paratexts to the Cahier from the 1940s underscore or at least suggest the importance of Africa and African culture in the poem, as well as the importance of the poem to Africa. However, Africa is not presented as the preponderant thematic element, and even less so as the cultural background of the poem. In the years immediately preceding the end of the colonial period, the paratext to the Cahier undergoes a transformation. Because Césaire was passionate about Africa and, more significantly, Africa was deemed throughout these years more culturally and geopolitically important than one small island in the Caribbean ("a bedsore on the sea," as Césaire calls it), the paratexts to subsequent editions downplayed or completely ignored the Caribbean content. As a result, the Cahier gets translated as an African text.

The 1969 English-language edition published in New York by Penguin for a North American audience performs precisely this kind of displacement, although the book cover does so less than the rest of the paratext. Gracing the cover is Picasso's famous Tête de nègre, a painting that in this context renders the text's provenance unclear. Picasso's painting shows the profile of a black man, but his precise identity remains unclear and, in a certain way, irrecuperable. Tête de nègre makes the Cahier the product of an indeterminate context: the text could be African, but it could just as easily be Caribbean or even North American. This ambiguous black figure who stares into the distance with apparent determination stands as an ideal of independence, but one that is not specific to any particular context. The fact that Tête de nègre is a painting by Picasso does something to mitigate the image's irrecuperability. The painter, who had shown himself on many occasions to be sympathetic to the politics of black liberation, nonetheless cast a large shadow in the art world and his presence in the paratext was still capable at that time of implying the text's indebtedness to the European avant-garde. Nonetheless, the cultural translation occurring in the visual paratext to this edition of the Cahier is broad enough to allow the contexts with which Césaire is the most concerned to be suggested: Africa, the Americas, and Europe. As with Breton's preface, it is racial difference in the text that is translated by the cover.

Whatever contextual ambiguity exists in the visual paratext to this edition is absent from the rest of the paratext. The promotional 
copy on the back cover refers to the Cahier as a "revolutionary African text" (Césaire, 1969, back cover [italics mine]), but does not mention the Caribbean. The preface, written by the South African poet Mazisi Kunene, also situates the Cahier squarely in the context of African decolonization and cultural renewal. This way of situating the text for a North American audience constitutes the erasure of another, more significant, element in the text: the Caribbean. Although this 1969 edition repositions the Cahier more forcefully than many other editions from the same period, a similar gesture appears in a French edition from 1956. The text is described as having been written for an African audience, and as dealing principally with African themes:

Sait-on que $[. .$.$] ce chant d'avant-garde, une jeunesse à peine$ scolarisée parfois, mais ardente et affamée, en récite des passages entiers en Afrique Française? Sait-on la ferveur et l'espoir suscités par cet étrange chef d'auvre parmi les élites locales en Afrique? [...] Comment s'explique ce succès? [...] [Ses lecteurs] admirent une virile et âpre descente aux enfers, expérience unique dans la culture africaine moderne. (Césaire, 1956, back cover)

The same gesture appears in a 1971 bilingual edition of the Cahier published by Présence Africaine. The anonymous copy on the back cover reads as follows: "A literary milestone, Césaire's Cahier d'un retour au pays natal not long ago burst upon the world like an advent. This considerable poem, which first appeared in 1939, will always inspire those from Africa and elsewhere who are thirsting for mankind's better future and just victories" (Césaire, 1971, back cover [italics mine]). That the Caribbean is relegated to the status of an elsewhere in the dust-jacket copy to this edition and is absent from the paratexts to the 1956 and 1969 editions is significant. The large thematic part of the poem in which Césaire describes the abjection and possible redemption of the pays natal, Martinique, is elided and becomes, implicitly, a prelude to the Cahier's assertions of Africanness. Why this is the case is not unclear: In the years immediately following decolonization in Africa, there was an intense interest on the part of Europeans and North Americans in the renewal of the African continent. These are also the years of Malcolm X's black nationalism, an ideology that promoted a return to African values. A 1960 s U.S. readership that followed "black literature" was more concerned with origins than with diaspora, and more interested in African "roots" than in Caribbean "rhizomes." Whereas the 1942 edition immediately establishes the Cahier as a text that stands at the crossroads of Europe, Africa, and the Caribbean, the paratexts to the 
editions from the 1950s through the 1970 s make the poem a product and a reflection of Africa, which is only part of the story.

Perhaps as a reaction to the redirection of the Cahier toward Africa seen in the paratexts of the 1950s through the 1970s and the poem's placement in the ambiguous category of "littérature négro-africaine" during those same years, more recent editions of the Cahier have sought to present the text in its original context. A forthcoming translation of the Cahier to be published by Wesleyan University Press will print the text with Breton's original preface and a glossary that defines the mostly Caribbean terms that might be unfamiliar to the reader. Two recent critical editions, one established by Mireille Rosello and the other by Abiola Irele, also bring a corrective to this problem of the text's incomplete or incorrect contextualization. Both underscore the Caribbean, African, and European elements in the text, discuss the conditions of its production, and describe the Cahier's relation to contemporary Caribbean literature. These editions of the Cahier in which the paratextual apparatus constitutes easily two thirds of the book are very useful in helping readers understand the meaning of the text and the context in which it was produced, and they also inadvertently suggest the place of the text today. If editions from previous decades attempted to attract an African audience (as well as a European and North American one) by highlighting the text's Africanness, the paratexts to these two editions indicate that the Cahier now resides in anglophone universities. The rich and thorough cultural translations of the Cahier in the editions prepared by Irele and Rosello are destined for an academic audience that either teaches the text or writes about it. In either case, the depth and accuracy of the cultural bracketing of the text is presented as more important than a virtually unmediated experience of the text.

But what exactly does it mean for a cultural translation to be accurate? Of this problem of the accuracy of translations as it relates to cultural anthropologists, James Clifford writes:

Cross-cultural translation is never entirely neutral; it is enmeshed in relations of power. One enters the translation process from a specific location, from which one only partly escapes. In successful translation, the access to something alien - another language, culture, or code - is substantial. Something different is brought over, made available for understanding, appreciation, consumption. At the same 
time, $[\ldots]$ the moment of failure is inevitable. An awareness of what escapes the 'finished' version will always trouble the moment of success. (Clifford, 1997, pp. 182-183)

The paratextual apparatus - constructed by the publisher who faces a dilemma similar to that of the anthropologist - is also subject to inevitable failure; the failure to position the work in relation to the original cultural context of its production. Sometimes the failures are complete: Just as there were European explorers, the first anthropologists, who returned from Africa reporting that they had encountered men with tails ${ }^{11}$, so are there cases of the paratext betraying the text that it frames. One contemporary example is that of the cover to a recent edition of Ferdinand Oyono's Une vie de boy. Judging by the picture of the smiling young boy on the front cover and the anodyne copy on both the front and back covers, one might think that one has an idyll of youth in colonial Africa in his or her hands, rather than the ironic skewering of colonial hypocrisy and cruelty from the perspective of an adolescent. (The most recent printing has a picture of an older, more sullen boy on its cover: It may well be that, having attained the status of a classic, Une Vie de boy no longer needs to be sold as something that it is not.) In Postcolonial Representations, Françoise Lionnet points to a similar example from the Mauritian context. Ananda Devi's 1988 novel La Rue Poudrière is a portrait of life in an old neighbourhood of Port-Louis, Mauritius, but the cover places the work in the sub-Saharan African context. Lionnet writes:

For a Francophone reader unfamiliar with Mauritius, this book cover creates a fictional world that is at least partially determined by the external reality of postcolonial urban Africa [...]. The combination of extratextual elements creates an imaginary Africa by means of visual details that anchor the narrative in a very specific though unknown locale. (Lionnet, 1995, pp. 54-56)

She then puts the following spin on an old chestnut: "(T)o judge the book by its cover may constitute a serious cultural and geographic misreading" (p. 56). This is in fact true of a good number of works from the Francophone corpus, beginning with the paratexts to the Cahier that seek to make it an African text for an African audience.

${ }^{11}$ See Christopher Miller's Blank Darkness: Africanist Discourse in French, esp. pp. 3-6. 
However, we should not, as Clifford reminds us, neglect the partial successes that precede the inevitable moment of failure. The pairing of Wilfredo Lam's drawings with Césaire's text constitutes just such a success, creating and fostering Caribbean aesthetic and even political connections that are relevant to the text ${ }^{12}$. Breton's preface, a bit too quickly dismissed by Mireille Rosello, should also be considered among the partial successes, for it translates part of the text's specificity (négritude) without reducing it to that specificity. Examining the paratext diachronically is useful even in the cases where the paratextual material has, in some way or other, been superseded. (Breton's preface feels dated as a work of criticism of Césaire's poem because it is dated; it does not respond adequately to our present concerns regarding the text.) The paratext is compelling, rather, for the story it tells about how cultural gaps were crossed, if not bridged, at certain historical moments.

Of course, the meaning of the text is largely a product of its signifying practices. Still, there is no experience of the text, of any text, that is unmediated. The text is inseparable from the text-object since the text is inevitably framed by paratextual material of some kind. The text is therefore always partially translated before it is read. Although this is true of all texts, the translation that occurs in the paratext of texts belonging to a minority discourse is always more intense, since those necessarily contain a higher quotient of "foreignness," and it is this foreignness that translations must resolve. Examining the uncharacteristically dense paratext to the many editions of the Cahier demonstrates how the impulse to frame this culturally different text changes over time and across cultures. It also shows how each new edition creates new versions - or new translations - of the poem, and how those translations respond to certain ideological imperatives. Sherry Simon writes that following the "cultural turn" in translation studies, we now tend to see "translation as a process of mediation which does not stand above ideology, but works through it" (Simon, 1996, p. 8). The same can be said of the translation effected by the paratext, which can become a lens for viewing the complex ideological struggles within which the text is situated, as well as the ideological appropriations to which it was subject. It is only in circulation that a

${ }^{12}$ It should come as no surprise that other literary texts from the Caribbean have come wrapped in Lam's work, from the re-edition of Césaire's journal Tropiques (1978) to Daniel Maximin's L'Isolé Soleil (1981), a work that, not coincidentally, pays hommage to Césaire and his generation. 
text assumes its significance, and the paratext is perhaps the most useful site for understanding how, for whom, and at what potential cost that significance was constructed.

\section{Tulane University}

\section{References}

Editions of Aimé Césaire's Cahier d'un retour au pays natal (listed chronologically):

(1942). Retorno al país natal. Pref. Benjamin Peret. Trans. Lydia Cabrera. Cover and illustrations by Wilfredo Lam. Havana, Cuba, Molina y Compania.

(1947). Cahier d'un retour au pays natal/Memorandum on my Martinique. Pref. André Breton. Trans. and pref. Ivan Goll and Emile Snyder. New York, Brentano.

(1947). Cahier d'un retour au pays natal. Pref. André Breton. Frontispiece by Wilfredo Lam. Paris, Bordas.

(1956). Cahier d'un retour au pays natal. Pref. Petar Guberina. Paris, Présence Africaine.

(1968). Return to my Native Land. Pref. Mazisi Kunene. Trans. John Berger and Anna Bostock. Cover by Pablo Picasso. Harmondsworth, Penguin Books.

(1969). Return to my Native Land. Pref. Mazisi Kunene. Trans. John Berger and Anna Bostock. Cover by Pablo Picasso. New York, Penguin Books.

(1971). Cahier d'un retour au pays natal/Notebook of a Return to my Native Land. Paris, Présence Africaine.

(1983). Cahier d'un retour au pays natal. Afterword by André Breton. Frontispiece by Wilfredo Lam. Paris, Présence Africaine.

(1994). Cahier d'un retour au pays natal. Edited, with Introduction, Commentary, and Notes by Abiola Irele. Ibadan, Nigeria, New Horn Press. 
(1995). Notebook of a Return to my Native Land. Pref. Mireille Rosello. Trans. Rosello with Annie Pritchard. Cover by Wilfredo Lam. Newcastle upon Tyne, Bloodaxe Books.

(2000). Cahier d'un retour au pays natal. Edited, with Introduction, Commentary, and Notes by Abiola Irele. $2^{\text {nd }}$ edition. Columbus, $\mathrm{OH}$, Ohio State University Press.

Other texts:

(1948). Anthologie de la poésie nègre et malgache. Ed. Léopold Sédar Senghor. Pref. ("Orphée noir") Jean-Paul Sartre. Paris, Presses Universitaires de France.

(1960). Anthologie des mythes, légendes et contes populaires d'Amérique. Ed. Benjamin Peret. Paris, Albin Michel.

BONGIE, Chris (1998). Islands and Exiles: The Creole Identities of Post/Colonial Literature. Stanford, CA, Stanford UP.

CÉSAIRE, Aimé, Éd. (1978). Tropiques : 1941-1945. Paris, JeanMichel Place.

CLIFFORD, James (1997). Routes: Travel and Translation in the Late Twentieth Century. Cambridge, MA, Harvard University Press.

GENETTE, Gérard (1997). Paratexts: Thresholds of Interpretation. Trans. Jane E. Lewin. New York, Cambridge University Press.

LÉVI-STRAUSS, Claude (1984). Tristes tropiques. Paris, Librairie Plon.

LIONNET, Françoise (1995). Postcolonial Representations: Women, Literature, Identity. Ithaca, Cornell University Press.

MAXIMIN, Daniel (1981). L'isolé soleil. Paris, Seuil.

MILLER, Christopher (1985). Blank Darkness: Africanist Discourse in French. Chicago, The University of Chicago Press.

OYONO, Ferdinand (1990). Une vie de boy. Paris, Presses Pocket. 
SIMON, Sherry (1996). Gender in Translation: Cultural Identity and the Politics of Transmission. London, New York, Routledge.

Front cover illustration of Retorno al país natal by Wilfredo Lam. Havana, Cuba, Molina y Compania, 1942 (see next page).

ABSTRACT : Translating Culture: Reading the Paratexts to Aimé Césaire's Cahier d'un retour au pays natal-This article is concerned not with the linguistic translation of a Caribbean text, but with its cultural translation. It presents the argument that the paratexts to the multiple editions of Aimé Césaire's Cahier d'un retour au pays natal function principally as instruments of cultural translation. It also describes how the transfigurations of the Cahier's paratext over time and across cultures serve as markers for the changing epistemes of "Caribbean culture" and "Francophone Caribbean Literature."

RÉSUMÉ : Traduire la culture : La lecture des paratextes au Cahier d'un retour au pays natal d'Aimé Césaire - Cet article traite non pas de la traduction linguistique d'un texte antillais, mais de sa traduction culturelle. Il présente l'argument que les paratextes aux nombreuses éditions du Cahier d'un retour au pays natal d'Aimé Césaire fonctionnent principalement en tant qu'instruments de traduction culturelle. Il décrit aussi comment les transfigurations du paratexte au Cahier à travers le temps et les cultures servent à marquer les épistémès changeants de la "culture antillaise" et de la "littérature francophone antillaise."

Key words: Césaire, Notebook, translation, paratext, francophone.

Mots-clés : Césaire, Cahier, traduction, paratexte, francophone.

Richard Watts: Department of French and Italian, Tulane University, New Orleans, LA 70118

Email: rwatts1@tulane.edu 


\section{A I ME CESA I RE}

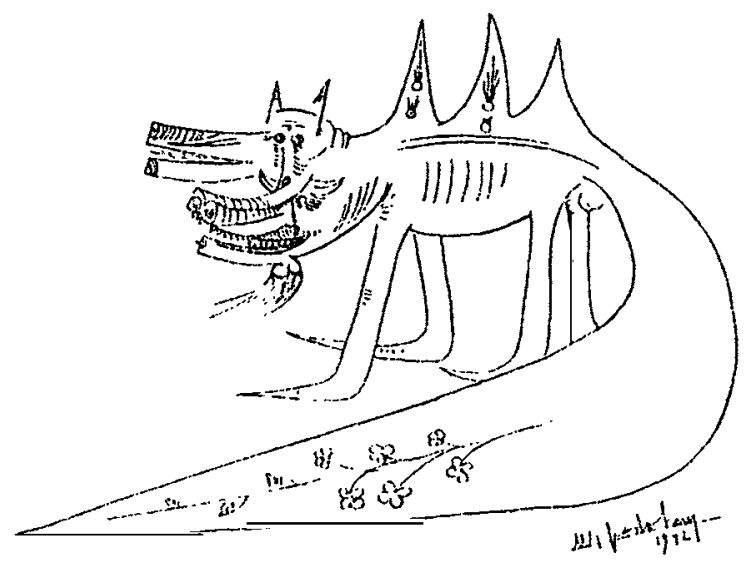

\section{RETORNO \\ AL PAIS NATAL}

PREFACIO DE BENJAMIN PERET ILUSTRACIONES DE WIFREDO LAM TRADUCCION DE LYDIA CABRERA COLECCION DE TEXTOS POETICOS 